\title{
Android Battle Game Based on Augmented Reality with 2D Object Marker
}

\author{
Muhammad Fauzan Azim ${ }^{1}$, Eka Wahyu Hidayat ${ }^{2}$, Andi Nur Rachman ${ }^{3}$ \\ ${ }^{1,2,3}$ Program Studi Teknik Informatika, Fakultas Teknik \\ Universitas Siliwangi, Tasikmalaya, Indonesia \\ ${ }^{1}$ m.fauzan.azim14@student.unsil.ac.id, ${ }^{2}$ ekawahyu@unsil.ac.id, ${ }^{3}$ andy.rachman@unsil.ac.id
}

\begin{abstract}
This research develops the game by applying the Augmented Reality system in making games. Similar games that have been observed have a weakness where the Augmented Reality characters that appear do not match the marker, there is no calculation of the distance between the marker card as a battle trigger, and no character has raised the urban legend. For this reason, it is necessary to make a similar game by applying the Based Tracking Marker technique by calculating the distance of action between two markers by raising the theme of urban legend Indonesia and foreign legend. This research succeeded in making Multimedia battle fighting game products using the Multimedia Development Life Cycle approach which introduced by Luther. Based on the tests that have been carried out, the alpha test results are functionally appropriate and from the beta testing the results of the User Acceptance Test functionalities obtained a value of $71 \%$ declared feasible to use with the interpretation of "Good" which means this game is feasible and can be developed.
\end{abstract}

Keywords-Augmented Reality, Game, Marker-Based Tracking, Multimedia

\section{INTRODUCTION}

Augmented Reality is the incorporation of twodimensional or three-dimensional virtual objects into a real three-dimensional environment, then projecting virtual objects in real time[1]. Marker-Based Tracking work by detecting the marker to determine the location and orientation of the camera, with the camera, calibrated then the system can then display virtual objects at a predetermined place[2]. According to this research[3], AR (Augmented Reality) is a technological breakthrough that makes users feel they are in a computer-generated environment.

Games are one of the media of technology that is popular among the public both from small children and adults as a media entertainment. The game itself has a lot of genres or types. There are types of Adventure, Simulation, Role-Playing Games (RPG), Real-Time Strategy (RTS), First Person Shooter (FPS), Fighting, and many other genres[4].

One example of a game that is common and widely known among game lovers is the fighting genre game. A fighting game is a fight between two characters in a place or arena with the aim to spend your opponent's finish off (health point). Fighting games, for example, Tekken games, Street Fighter games, Mortal Kombat games, and Bloody Roar games. The game is based on 2D and 3D objects as objects[5].

Special features for the interaction include the joystick with the use of the PlayStation console, the touchscreen on Android, and the mouse, or the keyboard on the PC. The technology used in console games causes the price of special consoles for games to be more expensive, for example, Playstation, Nintendo, Xbox which are expensive so they can only be played in certain circles of society. Now with the existence of Android-based games that include in smartphones, the game can be played by all groups.

This game is based on multimedia, multimedia can be interpreted as a combination of several media. Media can be in the form of text, images, videos, audio or animation. The combined media is then packaged into a single unit digitally manipulated with a computer[6][7]. The process of creating games is included in multimedia product engineering which consists of stages in the production of multimedia-based software, starting from the initial stages of preparation to system maintenance after completion and use[8]. There are several methods that can be used, namely the Vaughan method, the Luther method[9], the VillamilMolina method, and the Dastbaz method, the Godfrey method, and Sherwood-Rout[10][11].

Based on the problems and facts that have been described, the research solution that will be taken is designing and building battle game applications. The genre of the games that build is fighting genre game. In this game, multimedia technology is applied by utilizing Augmented Reality technology on Android-based smartphone systems with characters in the game that are 3D ghosts, with 2D card markers using Unity 3D. The purpose of this study is in addition to designing and building a Battle Game based on Augmented Reality fighting genre

(Muhammad Fauzan Azim, Eka Wahyu Hidayat, Andi Nur Rachman) 
Some of the things that are limiting the problem in this study are:

1. The concept of a game battle is a player vs computer and a marker used in the form of a card.

2. Gameplay fighting by choosing the character desired by the user and the fighting process or whoever attacks first is done by "hompimpa" with the concept of paperscissors-stone.

3. $3 \mathrm{D}$ ghost figures in the game raise the theme of urban legend ghost.

4. In the form of a card marker will be contain information on the story of the character.

5. The player has an HP for health points in each character, Physical Attack for how many physical attacks on each character.

The objectives to be achieved in this study are:

1. Build a game genre Battle Game by using Augmented Reality technology for android using unity game engine.

2. The detection process 2D Marker into the Battle Game android application using the Marker-based Tracking technique is to recognize and identify patterns in a marker so as to produce the character of a Virtual 3D object.

The benefit of this research is the development of Augmented Reality based fighting genre game products for Android platform with the concept of controlled character movement, besides that, making this game as a media of entertainment for the community.

\section{METHOD}

From several methods of device development available multimedia, the Luther method is considered most suitable for AR-based research[10]. The flow of research methods used in this study consists of several stages, namely: the stage of data collection, requirement analysis, designing multimedia products, and evaluating. System modeling in this study refers to the Luther version method.

\section{A. DATA COLLECTION}

This data collection is intended to collect data and materials that will support the creation of this application.

1. Literature Studies

Literature studies are conducted to support the research process in the form of looking for various theoretical references and conducting studies on previous studies by studying and reading books, research journals, articles from the internet related to this research.

2. Observation

This observation technique was conducted to find out how to play card game battle games in digital form using Augmented Reality technology in the general public.

\section{B. REQUIREMENTS ANALYSIS}

Analysis of requirements in making this application includes all the data needed for making an application, both input, and output, statements about what that must be done by the system, and characteristics that the system must have.

\section{MULTIMEDIA PRODUCT DESIGN}

The design method in this study uses Multimedia Development Life Cycle (MDLC). Luther introduced this method in 1994.The following steps showed in figure 1 which contain previous stages (data collection and requirement stages).

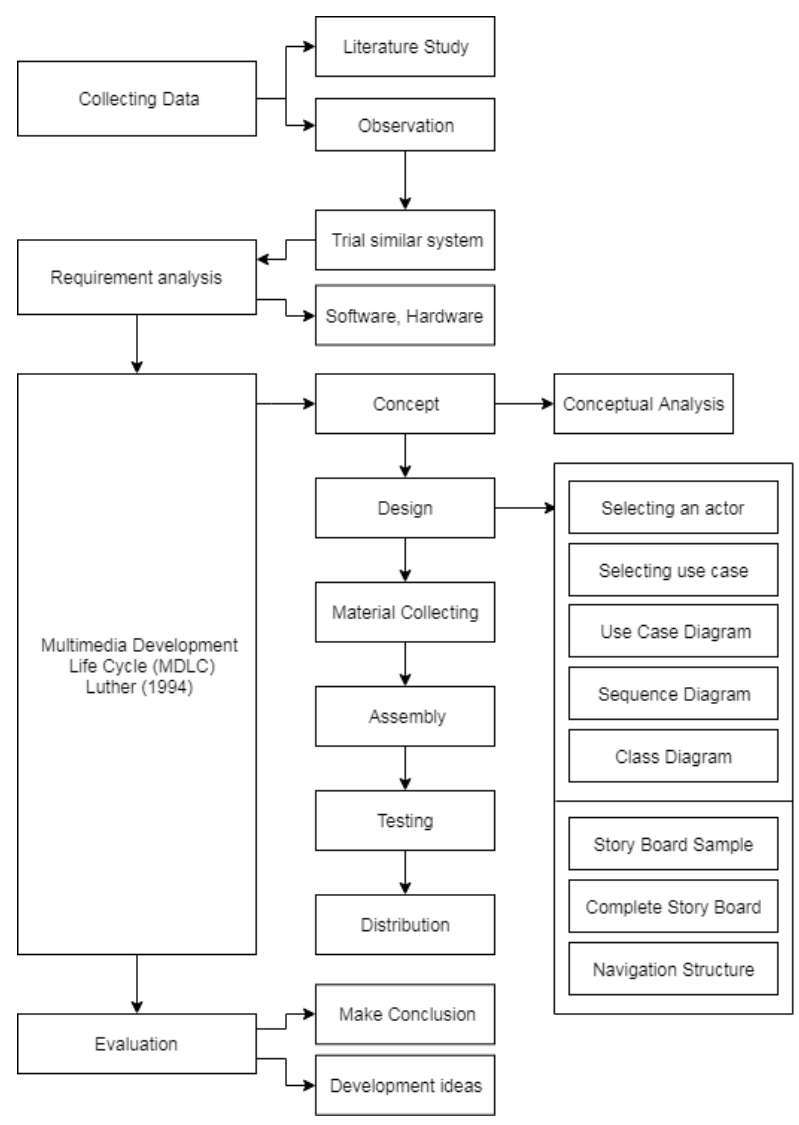

Figure 1. Research Methodology

Multimedia Development Life Cycle (MDLC) consists of several steps such as Concept, Design, Material Collecting, Assembly, Testing, Distribution. The detail explanation as written below.

1. Concept, in the concept stage, the target user or user of the game will be determined, the purpose of the game application that will be built later and general specifications.

2. Design, at this stage the specifications will be made about the program architecture, style, appearance and material or object requirements for the program.

3. Material Collecting, at this stage it is done to collect what data is needed to design and build game applications and collection of materials according to the needs to be worked on.

4. Assembly, at this stage all the objects of multimedia materials needed built.

5. Testing, the next step is to test the game application by running an application or program and seeing whether there is an error or not. This stage is also called the alpha testing stage (alpha test and beta test) where 
testing is carried out by the maker or the creator's own environment.

6. Distribution, the last stage is the distribution stage, where this stage will be carried out if the application has fulfilled the main targets and targets according to what has been determined at the concept stage. This step will check whether the application is suitable for use by the user. If it is feasible, the application will publish to be used by the user.

\section{EVALUATION}

The stages are carried out after all the process of making the application has been successfully carried out including the drawing of conclusions and the idea of development.

\section{RESULTS AND DISCUSSION}

\section{A. CONCEPT}

The stages that will be developed and will be built based on existing ideas, to determine goals, identify users, types of products, basic rules, sizes, and targets. The results of this stage can be seen in table 1 .

Table 1. Concept Description

\begin{tabular}{|c|c|}
\hline Title & ARC-B DIMENSION \\
\hline Audiences & Public \\
\hline Duration & Unlimited \\
\hline Animation & Character Animation 3D (*.FBX) \\
\hline Audio & Instrument $(* . \mathrm{MP} 3)$ \\
\hline Image & $\begin{array}{l}\text { Background Pictures, Icon, Button } \\
\text { (*.PNG dan *.JPG) }\end{array}$ \\
\hline Teks & $\begin{array}{l}\text { Write stories on each character, } \\
\text { instructions in game }\end{array}$ \\
\hline Interactivity & Button and link \\
\hline Theme & Fighting genre game \\
\hline Character & 6 Characters \\
\hline $\begin{array}{l}\text { Application } \\
\text { Description }\end{array}$ & $\begin{array}{l}\text { This game application tells about the } \\
\text { battle of ghosts between two different } \\
\text { dimensions namely the dimensions of } \\
\text { ghosts in the country (Indonesia) and the } \\
\text { dimensions of foreign ghosts. Their } \\
\text { dimensions are open to each other because } \\
\text { a genius child who always likes to do an } \\
\text { experiment named Sentou made it into it, } \\
\text { then catches all the ghosts and seals them } \\
\text { into a card then the ghosts must fight in } \\
\text { order to become the strongest and the } \\
\text { rewards will be able to explore between } \\
\text { dimensions not fixed in just one } \\
\text { dimension and became king in both } \\
\text { dimensions. }\end{array}$ \\
\hline
\end{tabular}

\section{B. DESIGN}

This stage of design must be carried out in detail starting with the initial description of the product.

Table 2. Short Story Board

\begin{tabular}{l}
\hline Story Board in every Scene \\
\hline Scene 1: Opening and display of application logo \\
\hline Scene 2: Display application logo and loading bar \\
\hline Scene 3: Display the main menu with the Fighting, How to Play, \\
About and Exit menu \\
\hline Scene 4: Display fighting of battle game Augmented Reality \\
\hline Scene 5: Information display tutorial how to play the game
\end{tabular}

\section{Story Board in every Scene}

Scene 6: Information display tutorial how to play the game

Scene 7: Information display tutorial how to play the game

Scene 8: Information display tutorial how to play the game

Scene 9: Information display tutorial how to play the game

Scene 10: App Information Display

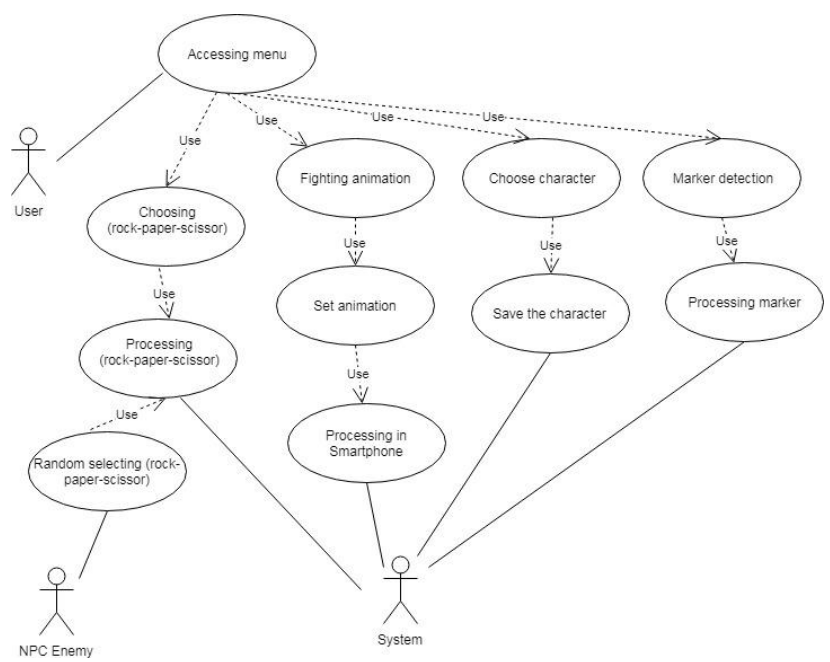

Picture 2. Fighting Use Case Diagram

Use Case Diagrams describe patterns of system behavior and sequences of activities carried out by actors and NPC enemies. Flowchart in picture 3 serves to explain the flow of marker detection process.

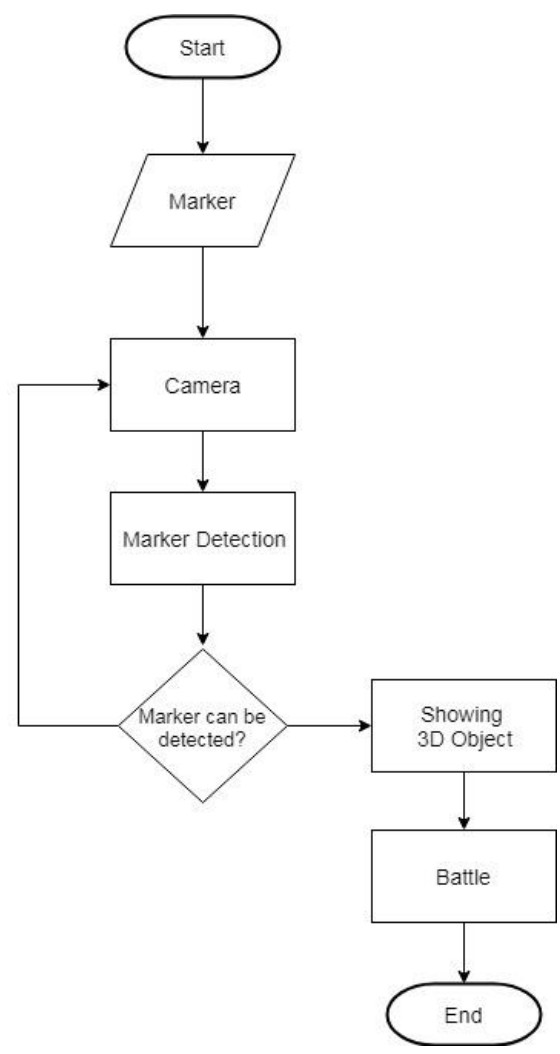

Picture 3. Displaying 3D Model

C. MATERIAL COLLECTING 
This material collecting stage is the stage where everything that has been prepared to make an application has begun to be processed. The stages include:

1. Marker 2D

Used as a marker or target object that serves to identify $3 \mathrm{D}$ objects that will be displayed. The urban legend figures include Kuntilanak, Tuyul, Pocong, Zombie, Slenderman and Sadako.
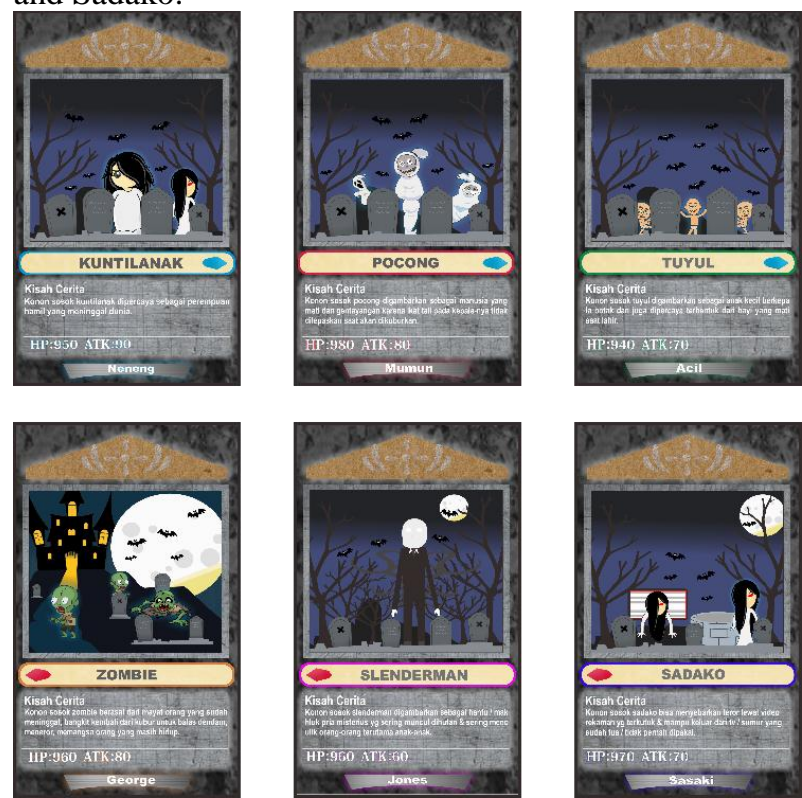

Picture 4. Display marker urban legend

2. Detection Marker

The results of Marker detection are by introducing patterns by detecting or tracking points (interest points) and (corners) on an image.

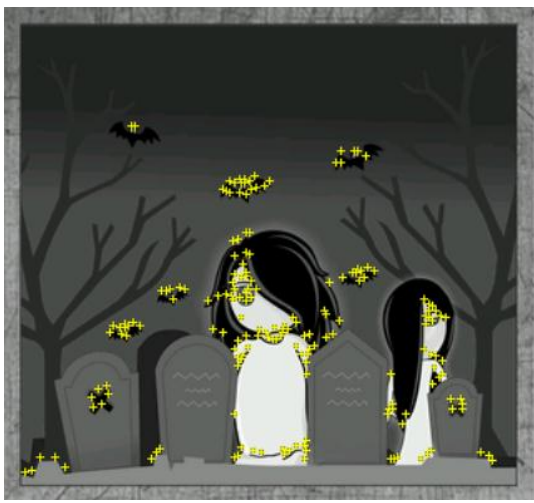

Picture 5. Marker Detection Results

3. 3D Object

Making 3D objects and animations using Blender. The results of 3D ghost objects urband legend figures include:

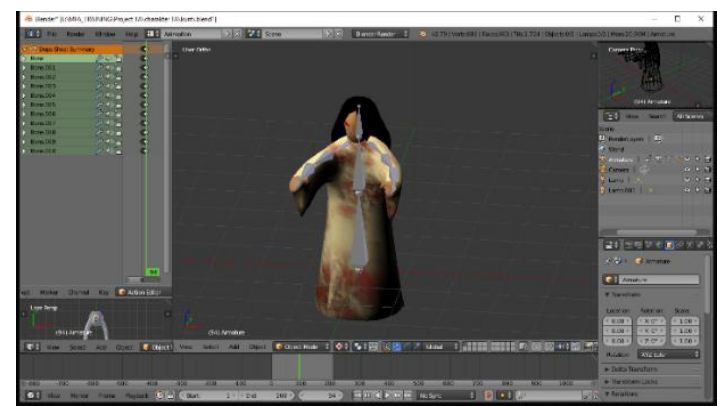

Picture 6. Example one of the Kuntilanak 3D Models

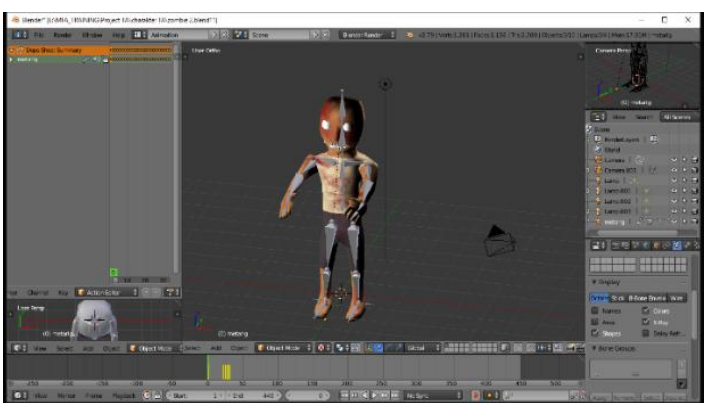

Picture 7. Example one of the Kuntilanak 3D Zombie

\section{ASSEMBLY}

This assembly stage includes the merging of all multimedia elements into one unit, the multimedia elements needed and will be designed including text, images, video, audio, animation. All these elements will be combined into unity software, so that the desired results are in the form of an Augmented Reality application that can be used on an Android device, as for the results in the assembly stage, namely:

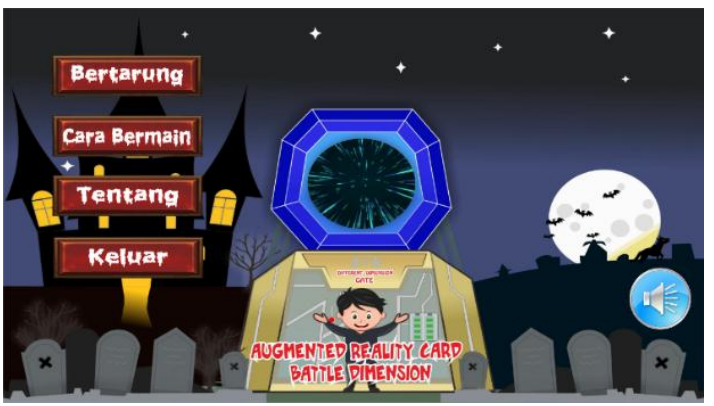

Picture 8. Menu Course

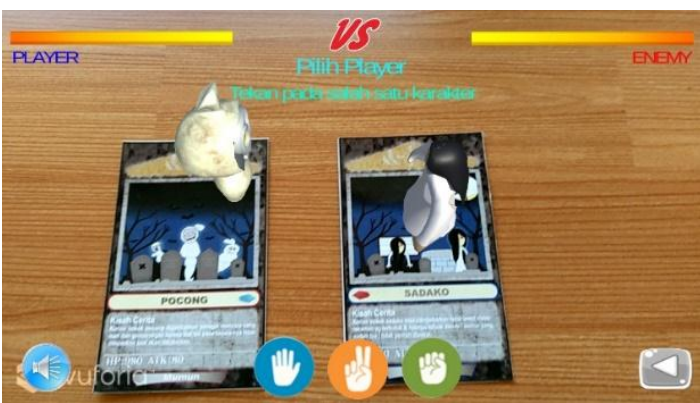

Picture 9. Menu Fighting 


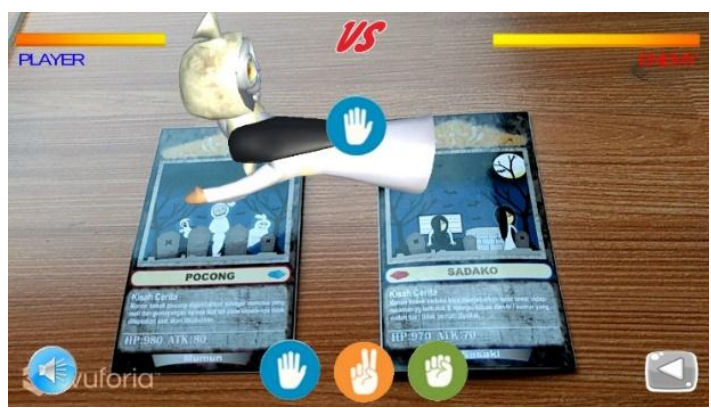

Picture 10. The Concept of Fighting Game

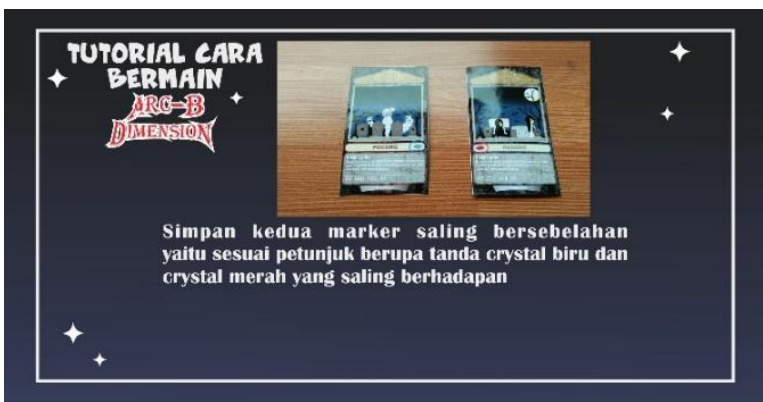

Picture 11. How to Play Menu

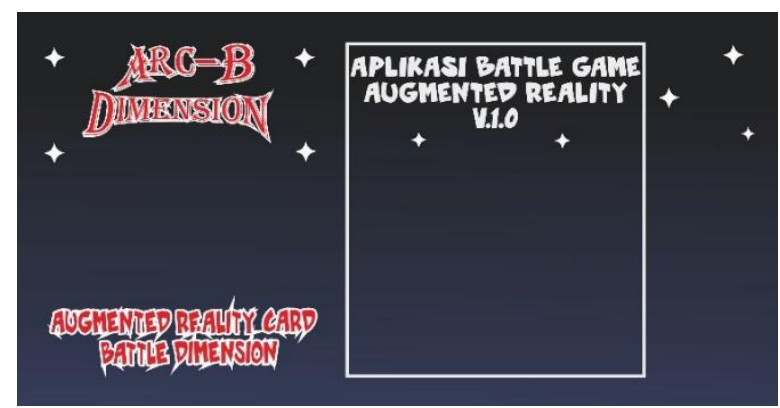

Picture 12. About Application Menu

\section{E. TESTING}

1. Alpha Test

Alpha testing is done by developers with the BlackBox Testing method. The conclusion from the Alpha test is that all functions in the application are running well.

\begin{tabular}{lll}
\hline \multicolumn{1}{c}{ Tested Menu } & \multicolumn{1}{c}{ Details of Testing } & Result \\
\hline Navigation button & move of each scene & accepted \\
\hline Fighting Menu & $\begin{array}{l}\text { Scanning markers displays 3D } \\
\text { ghost objects in the country and } \\
\text { foreign ghosts showing character } \\
\text { selection }\end{array}$ & accepted \\
\hline $\begin{array}{l}\text { Menu How to } \\
\text { Play }\end{array}$ & $\begin{array}{l}\text { Display information on how to } \\
\text { play augmented reality battle } \\
\text { game application }\end{array}$ & accepted \\
\hline About menu & $\begin{array}{l}\text { Display information about the } \\
\text { application }\end{array}$ & accepted \\
\hline Exit menu & Exit from application & accepted \\
\hline
\end{tabular}

2. Beta Test

This beta test will be collected using the survey method in the form of filling out questionnaires to end users. The purpose of this questionnaire is to get feedback or feedback from users who will play the game that has been made. Beta test is done to get the function by considering the learning aspects of information, namely VISUALS.

Design of questions on the questionnaire with the VISUALS approach. The collected material is presented in simple and communicative languages complemented by other multimedia components by observing the concept of VISUALS [4], namely:

1. Visible or easily seen, namely the material presented is visually clearly visible, the level of high readability, high resolution or sharpness of graphics, contains one meaning.

2. Interesting, namely the content of the message according to the needs of the audience, the appearance of good and charming so that it creates curiosity, and tries to maintain the continuity of the process of communication or interaction and learning.

3. Simple, namely focused messages, selection of words, letters, images do not change the meaning of messages, language and straightforward appearance.

4. Useful, which is in accordance with the needs of the audience and the learning objectives and learning outcomes desired.

5. Accurate, that is the content of the message has the right meaning, according to the needs, the delivery is accurate, based on sources that can be accounted for.

6. Legitimate, namely the content of the message is correct, arranged logically, follows scientific rules, and makes sense.

7. Structure or structured, namely a series of messages delivered systematically, in logical and easily understood sequences.

Beta test testing is done by distributing questionnaires also distributed in the general target population amounting to 100 people and to determine the number of respondents only taken samples are calculated using the Slovin method[12]. The results of calculations that have been done using the Slovin method, obtained as many as 30 respondents who were sampled to fill this questionnaire.

After determining the number of respondents, the questionnaire was distributed as many as the number of respondents who had been counted. Then the percentage of each questionnaire answer is identified using the formula:

Keterangan:

$$
Y=P / Q * 100 \%
$$

$\mathrm{Y}=$ Percentage Value

$\mathrm{P}=$ Number of respondents' answers to each question

$\mathrm{Q}=$ Number of respondents

The total respondents who filled out questionnaires were 30 people. To determine the category of interactive multimedia validity level, the scale rating rating scale is used. The following is the percentage of the results of the questionnaire with choices "Baik":

Table 4. Questionnaire Results Answers "Baik"

(Muhammad Fauzan Azim, Eka Wahyu Hidayat, Andi Nur Rachman) 


\begin{tabular}{cc}
\hline Question & Percentage of Answers (\%) \\
\hline 1 & 96,67 \\
\hline 2 & 86,67 \\
\hline 3 & 60,00 \\
\hline 4 & 86,67 \\
\hline 5 & 50,00 \\
\hline 6 & 80,00 \\
\hline 7 & 80,00 \\
\hline 8 & 63,33 \\
\hline 9 & 80,00 \\
\hline 10 & 70,00 \\
\hline 11 & 76,67 \\
\hline 12 & 73,33 \\
\hline 13 & 40,00 \\
\hline 14 & 50,00 \\
\hline 15 & 56,67 \\
\hline 16 & 36,67 \\
\hline 17 & 80,00 \\
\hline 18 & 90,00 \\
\hline 19 & 76,67 \\
\hline 20 & 73,33 \\
\hline 21 & 76,67 \\
\hline 22 & 80,00 \\
\hline SUM & $15,63333 / 30=71 \%$ \\
\hline
\end{tabular}

The highest percentage value of the answer above is included in the results table of the questionnaire above. Obtained a total percentage of $71 \%$ of "Baik": answers after divided by the total number of questions in the questionnaire, namely Assessment is determined based on the level of interactive multimedia validation categories that use the scale rating scale.

Table 5. Validation Level Category

\begin{tabular}{ll}
\hline Percentage (\%) & Percentage (\%) \\
\hline $0-25$ & Tidak Baik \\
\hline $26-50$ & Kurang Baik \\
\hline $51-75$ & Baik \\
\hline $76-100$ & Sangat Baik \\
\hline
\end{tabular}

\section{F. DISTRIBUTION}

This stage distribution produces an ARC-B DIMENSION product packaged in a DVD box inside it equipped with game application on DVD, application guides, and 6 markers.

\section{CONCLUSION}

\section{A. ADVANTAGES AND DISADVANTAGES}

The advantages of the Battle Game android application based on Augmented Reality are as follows:

1. The $3 \mathrm{D}$ ghost object is displayed according to the placement in each of its markers.

2. The concept of the game refers to card games that are used traditionally such as fighting cards and paperscissors-stone suits.

3. This multimedia product is equipped with a usage guidebook to add information about the use of Android Battle Game applications based on Augmented Reality.
The disadvantages of the Battle Game android application based on Augmented Reality are as follows:

1. Games cannot be played Multiplayer.

2. The application cannot run under the Android OS Jelly Bean.

3. Does not have the level and score of the game.

\section{B. CONCLUSION}

Based on the results of this study, it was obtainedconclusion as follows:

1. Application genre battle game has been produced that is a product called ARC-B DIMENSION which can run on Android smartphone, also can provide new and different experiences for users in playing games using Augmented Reality technology by lifting urban legend with ghost objects as main characters in the game and the process of making 3D unity.

2. The results of 2D marker detection using markerbased tracking technique are pattern recognition by detecting or tracking points and interest points on an image and then doing edge analysis to get the right angle detection.

\section{SUGGESTION}

Based on the research that has been done can be given some suggestions as follows:

1. The application is more interesting if you add more ghost 3D object characters that can be involved in the ARC-B DIMENSION application and add more animated movements to each 3D object character.

2. Add levels and scores in the ARC-B DIMENSION application.

3. Adds a setting feature to adjust pause when battle games take place.

4. Can be played in multiplayer.

\section{REFERENCES}

[1] R. T. Azuma, "A Survey of Augmented Reality," Presence Teleoperators Virtual Environ., vol. 6, no. 4, pp. 355-385, Aug. 1997.

[2] S. Siltanen, Theory and applications of marker-based augmented reality. 2012.

[3] R. S. Ernawati, E. W. Hidayat, and A. Rahmatulloh, "Implementasi Teknologi Augmented Reality Sebagai Media Pengenalan Aksara Sunda Berbasis Android," J. Tek. Inform. dan Sist. Inf., vol. 3, no. 3, 2017.

[4] Suharian and Emigawati, "Pembuatan Game 3D Fighting dengan Menggunakan Finite State Machine Sebagai Strategi Karakter," J. Ilm. MATRIK, vol. 10, no. 1, pp. 18-32, 2008.

[5] Troy, "Tinjauan Historis Kecerdasan Buatan Dalam Games," J. Animat. Games Stud., vol. 1, no. 2, pp. 135164, Apr. 2016. 
[6] B. S. D. Oetomo, E-Education: Konsep, Teknologi, dan Aplikasi Internet Pendidikan. ANDI Yogyakarta, 2007.

[7] T. Vaughan, Multimedia: Making It Work, Sixth Edition. McGraw Hill Technology Education, 2004.

[8] I. Sommerville, Software Engineering. Pearson Education Inc., 2011.

[9] E. W. Hidayat and E. P. Irawan, "Prototype Informasi Digital Jurusan Teknik Informatika UNSIL Berbasis Multimedia," in Konferensi Nasional Sistem Informasi 2013, 2013.

[10] B. Permana, E. Wahyu Hidayat, and A. Rahmatulloh, "Aplikasi Ensiklopedia Pakaian Adat Dunia Berbasis Android," J. Inform. J. Pengemb. IT, vol. 3, no. 2, pp. 151-156, May 2018.

[11] I. Binanto, "Tinjauan Metode Pengembangan Perangkat Lunak Multimedia Yang Sesuai Untuk Mahasiswa Tugas Akhir," in Seminar Nasional Rekayasa Komputer dan Aplikasinya, 2015.

[12] S. Ellen, "Slovin's Formula Formula Sampling Techniques." 